\title{
Insured and non-insured livestock farmers' perception toward livestock insurance- a case study of Faisalabad-Pakistan
}

\author{
M.H. Mahboob ${ }^{1 *}$, Q.M. Rehman ${ }^{1}$, K. Hamid ${ }^{2}$, M.Y. Saeed ${ }^{3}$
}

\begin{abstract}
${ }^{1}$ Institute of agriculture and resource economics, university of agriculture Faisalabad, Pakistan, 38040; Institute business management sciences, university of agriculture Faisalabad, Pakistan, 38000; ${ }^{3}$ Preston University Islamabad, Pakistan
\end{abstract}

*Corresponding author email: m.hassan1695@gmail.com

Journal of Livestock Science (ISSN online 2277-6214) 10: 48-52

Received on 16/4/2019; Accepted on 20/6/2019

doi. 10.33259/JLivestSci.2019.48-52

\begin{abstract}
In Pakistan insurance markets regarding livestock insurance are not working efficiently as compare to other countries. Major concern is lack of awareness in livestock farmers (LFs) which been not adopted correctly in Pakistan from last 30 years. Through livestock's farming; many risks that can reduce the productivity of LFs; like diseases, natural disasters, theft risks, climatic conditions and peril hazards. The main ambition of this study was to study the socio-economic characteristics of LFs as well as to check their level of willingness to pay (WTP) for livestock insurance in district Faisalabad. To achieve the objectives of this study, primary data were collected from livestock farmers through a well-designed questionnaire. Data were collected from 300 livestock farmers (insured \& non-insured equally) through convenient sampling from districts (7) Faisalabad in the months of January to March 2018. Contingent valuation method was employed for WTP and dichotomous (YES/NO) and premium level was used to assess the WTP. Mostly insured farmers were approached through insured companies and banks. Three insurance companies were working in Faisalabad right now; namely, Jubilee General Insurance Company Limited, Adamjee Insurance Company Limited and United Insurance Company Limited. For descriptive analysis and econometrics analysis, MS-Excel and SPSS software were used respectively. Majority of the livestock farmers had cows and buffalos. Binary logistic regression model was used for the estimation of WTP of the LFs. The results of the study showed; majority of the LFs were matured in the age and having low level of education and were satisfied regarding income level. The results indicated that; age, education and land holding were significant determinants of WTP. On the basis of results; valuable policies were suggested. Awareness regarding livestock insurance by livestock management authorities and government through electronic media and other sources are much important for the livestock farmers to increase their productivity.
\end{abstract}

Key words: Livestock farmers; livestock insurance; Pakistan 


\section{Introduction}

Pakistan is an agricultural country and its success is directly linked with the prosperity of agricultural industry and its allied departments. Seventy seven million people in Pakistan can now be considered food insecure because of rising food prices. It is expected that in future demand for livestock products will increase at higher rate due to the growth in population, and will bring direct increase in the demand of livestock products and animal based products are required for fulfilling the protein and calcium requirement of the population on health ground (Banbury, 2008). Livestock industry is a dynamic, generating, and employment boosting industry. For economic growth livestock sector is a major segment after agriculture particularly among development nations of the world. Livestock segment acts as a fuel for engine to increase income, better growth, and foreign exchange earnings food for better nutrition level and very importantly it provides employment opportunities (Dayanandan, 2011).

In Pakistan livestock sector suffered from many risk that lead to a huge losses, the most serious risk is diseases. Among numerous of disease, mastitis is a tenacious hazard for dairy cultivating and generation of milk (Dua 2001). Mastitis is a danger of health and dairy animals will responsible for the financial losses (Cady et al., 1983). Mastitis exist invisible as well as visible illness in which swelling of mammary nerve rises that effect abundant marketable sufferers in dairy making (Khan and Khan, 2006). Some other diseases are bacterial diseases like "Hemorrhagic septicemia" which reasons to be death to about $50-100 \%$ and it spreads in different parts of Pakistan including Punjab and Sindh. This disease was seasonal happening in rainy period of the year, buffalo and cattle are the victim. There is another important economic viral disease that is "foot and mouth diseases" (FMD) which causes a lot of economic losses, the approximate loss US\$ 18 million in Pakistan due to this disease in 2003 (PARC, 2018). Other disease that faced in livestock is "Infectious Bovine disease" (IBD), "Bovine viral diarrhea" (BVD). Further risk that livestock area faced like theft risk loss of animals and climate extremities use a great loss.

As per the 2006 survey, Punjab controlled Pakistan's livestock part. Reportedly the area had $66 \%$ of buffaloes, 50\% of cows, $38 \%$ of goats, and $25 \%$ of sheep. The sector of livestock is gradually structured in extensive market place that minimum at 1.3 billion employment persons generally and openly sustenance and maintenances of 600 million deprived smallholder growers at emerging world (Thornton et al., 2002). Livestock foods give $17 \%$ to kilo calorie consumption and protein consumption 33\% internationally, but among poor and rich countries there are huge differences (Nelson et al., 2009). Livestock organizations have both negative and positive properties on the base of the natural resource, social equity, economic growth and public health. In Faisalabad small farmers usually keep 1 to 2 milk animals as per a share of varied rural method organize near 38 percent of whole asset of milk animals in Pakistan. Through, in livestock sector of Punjab is little linked by the market globally in the production of milk (Shabbir, 2011).

Risk management plays a really important role in the development of livestock farming. ). Livestock insurance is one of the most useful and important risk management tools to stabilize livestock farmer's income. In developed countries, agricultural insurance has been developed well. Public support to livestock insurance is necessary for its development especially in the incipient stage which can encourage livestock insurance to take an active role in risk management and participate in insurance systems. Livestock insurance is a valuable business in risk management tool that provides farmers with financial protection against production losses caused by natural perils, such as drought, excessive moisture, wind wildlife and the insurance covers. All the insurance contracts which undertakes by the insured versus compensate him for any loss incurred during the period of the contract.

Despite the existence of insurance services rendered by Pakistan's livestock Insurance Corporation and other private firms in Faisalabad and overall in the country; there has been a low level of participation of livestock farmers buying insurance premium. It is in the light of the above that this study was conceived to examine determinants of participation of livestock farmers in livestock insurance in district Faisalabad. The specific objectives are (a) to study the Socio-economic characteristics of livestock farmers; (b) to estimate the level of willingness to pay of livestock farmers for livestock insurance.

\section{Materials \& Methods}

The present study was carried out in all 7 districts; Madina town, Iqbal town, Chak Jhumra, Jaranwala town, Sumandari town, Jinnah town and Tandlianwala Faisalabad, Pakistan which is $3^{\text {rd }}$ largest city of Pakistan in the prospective of population.

\section{Questionnaire and Interviews}

A well designed questionnaire was developed through pre-testing and existing literature. Questionnaire was developed in English and interviews and survey was conducted in local language (Urdu and Punjabi) due to uneducated of livestock farmers; questionnaire covered the socio-economic characteristics of the LFs like age, 
education, income etc, willingness to pay for insurance and participation rate was collected. WTP (0 NO, 1YES); questions were used in the questionnaire were open ended and close ended.

\section{Contingent valuation method (CVM)}

"Agricultural insurance has characteristics of quasi-goods. The studies regarding agricultural farmers' willingness to pay (WTP) for 1 insurance has been explored enough; but livestock farmers WTP can be measured through CVM. The contingent valuation method is one of the typical non-market valuation methods. CVM is a survey based economic technique of valuation of non-market resources. WTP can be obtained through open ended questions and other is dichotomous questions (YES/NO) for given maximum WTP premium (Xing, 2003).

\section{Data collection and sampling procedure}

The primary data were obtained with the help of questionnaire. Data were collected in the months of January to march 2018. Simple random sampling technique was employed for the respondent's selection; a sample of 150 was selected.

\section{Data Analysis}

Data were analyzed with descriptive statistics and binary logistic model. The descriptive analysis were used to over-view of the socio-economic characteristics of the livestock farmers through MS-Excel and binary logistic model used to examine the WTP of the livestock farmers for insurance; equation given below (i).

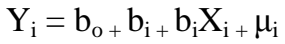

Where $\mathrm{Yi}=$ Dichotomous variable $($ Yes and No), Where $\mathrm{Yi}=$ (final premium)

$\mathrm{B}_{\mathrm{is}}=$ Coefficients to be determined,

$\mathrm{X}_{\mathrm{i}}=$ Independent variables like age, education, income, land holding,

\section{Results and Discussion}

Socio-economic characteristics of the livestock farmers studied in which both included insured farmers and non- insured farmers. As results indicate male livestock farmers insured and non insured are in majority 97.3 percent and 96 percent respectively. In the context of age, insured livestock farmers most of them above 40 years and noninsured farmers were also above 40 years. According to marital status insured and non-insured farmers were married $106 \%$ and $77.3 \%$ respectively. Insured farmers having up to 5 family members were 53 percent and non-insured were also fall in this category and second other were fall in other categories. Majority of the livestock farmers were those who had primary level of education $(47 \%)$ and in the non-insured farmers were uneducated in the percentage. Income level was high of insured and non-insured farmers who earns up to 100,000 rupees monthly, other were having up to 50,000 rupees. Insured farmers in livestock farming experience 43 percent were having up to 10 years and second in non-insured were having up to 10 years and majority of the non-insured were 35 percent who were involving up to 5 years. Regarding landholding area in (acers) insured were had up to five acers and non-inured were holding up to 10 acers (64 percent).

The perception of insured livestock farmers toward livestock insurance, their major source of information to getting knowledge about livestock insurance was banks and insurance agents 34.67 percent and 29.33 percent respectively. Majority of the livestock farmers became insured due to animal's diseases and that percentage is 73.33 percent. Majority of the insured farmers (78.67) satisfied regarding veterinary hospitals in their area and 90 percent have the access toward bank loans and other loans. More than half of the insured farmers 58.67 percent were those who took the loan up to 300,000 rupees. More than half of the livestock insured farmers took the loans to purchase dairy cows and those percentage is 57.33. Majority of the respondents were newly insured and that percentage is more than half. Almost equal percentage of those livestock farmers who got benefits from loans through productivity increase and to safeguard livestock activities for upcoming time and insured farmers were satisfied to get insured.

The livestock farmers perception who were not insured more than half of the respondents who were not willing to pay for livestock insurance due to lack of knowledge about insurance of livestock and other percentages are very low. Less than half 34.67 percent were those who wants to get insurance through insurance agents and 25.67 percent wanted to get loans though banks and last question's percentage was almost equal 5.33 percent and 46.67 percent were familiar to livestock insurance and were not familiar to livestock insurance respectively.

The distribution of livestock farmers regarding their animals /birds which they have in majority is indicated in Table 1; 38.67 percent insured livestock farmers had buffalos and 32.67 percent had cows and non-insured livestock farmers were had also buffalos (66\%) and other were in low ratios. Very close percentage 56 percent and 44 percent insured farmers were still willing to pay for and not-willing to pay for insurance respectively. In noninsured farmers 45.33 percent were willing to pay for livestock insurance and 54.67 percent were not willing to pay 
for livestock insurance. The insurance premium rates which were given to insured and non-insured farmers how much they are willing to accept for livestock insurance premium. More than half $56 \%$ were accepted up to 2 percent premium and 54.67 percent were those who were not insured farmers but they would like to accept up to $1 \%$ premium rate given in (table 2).

Table 3 shows the determinants of livestock farmers who were tested through binary logistic model and ordinary least square (OLS). As results indicate age of insured livestock farmers was the only determinant of farmer's WTP for livestock insurance; on the other hand age and education level negatively related with WTP and also were significant determinants.

Table 4 results indicate the non-insured farmers WTP and their determinants. Age negatively and significant determinants in binary logistic model and land holding area was positively related and has significant determinant was found. In OLS model age of non-insured farmer's negatively related and significant determinant was founded highly significant.

Table-1: Distribution of livestock farmers regarding animals/birds which they have in majority

\begin{tabular}{|c|c|c|c|c|}
\hline \multirow[t]{2}{*}{ Majority of the Animals/birds } & \multicolumn{2}{|c|}{ Insured livestock farmers } & \multicolumn{2}{|c|}{ Non-insured livestock farmers } \\
\hline & Frequency & Percentage & Frequency & Percentage \\
\hline Cows & 49 & 32.67 & 25 & 16.67 \\
\hline Buffalos & 58 & 38.67 & 99 & 66 \\
\hline Goats & 17 & 11.33 & 10 & 6.67 \\
\hline Horses & 05 & 3.33 & 02 & 1.33 \\
\hline Camels & 15 & 10 & 05 & 3.33 \\
\hline Goats/sheep's & 04 & 2.67 & 08 & 5.33 \\
\hline Birds (hen, duck, parrots etc.) & 02 & 1.33 & 01 & 0.67 \\
\hline
\end{tabular}

Source: Survey's data $(n=300)$

Table-2: distribution of livestock farmers regarding their willingness to pay (yes/no) for livestock insurance and their participation at given premium level

\begin{tabular}{|c|c|c|c|}
\hline Are you WTP for livestock insurance & Frequency & Percentage & Prequency \\
\hline Yes & 84 & 56 & 68 \\
\hline No & 66 & 44 & 82 \\
\hline Up to 1\% & 42 & 28 & 82 \\
\hline Up to 2\% & 84 & 56 & 40 \\
\hline Up to 3\% & 22 & 14.67 & 25 \\
\hline More than 3\% & 02 & 1.33 & 26.67 \\
\hline
\end{tabular}

Source: Survey's data (n-300)

Table-3: determinants of livestock farmers' (Insured) participation in livestock insurance

\begin{tabular}{|c|c|c|c|c|}
\hline Variables & \multicolumn{2}{|c|}{ Binary logistic } & \multicolumn{2}{|c|}{ OLS } \\
\hline Dependent variable & \multicolumn{2}{|c|}{ WTP (Yes/No) } & \multicolumn{2}{|c|}{ Final premium } \\
\hline Independent variable & B & Std. & $\mathrm{B}$ & Std. \\
\hline Age of LFs & $-.106^{* *}$ & .024 & $-.010^{* *}$ & .006 \\
\hline Education level of insured LFs & $-.159^{*}$ & .061 & $-.006 * *$ & .018 \\
\hline Income level of insured LFs & 0.000012 & .00009 & 2.17 & 0.00003 \\
\hline Land Holding (Acres) under LFs & -.214 & .385 & .173 & .111 \\
\hline
\end{tabular}

Table-4: determinants of livestock farmers' (Non-Insured) participation in livestock insurance

\begin{tabular}{|c|c|c|c|c|}
\hline Variables & \multicolumn{2}{|c|}{ Binary logistic } & \multicolumn{2}{|c|}{ OLS } \\
\hline Dependent variable & \multicolumn{2}{|c|}{ WTP (Yes/No) } & \multicolumn{2}{|c|}{ Final premium } \\
\hline Independent variable & $\mathrm{B}$ & Std. & B & Std. \\
\hline Age of LFs & $-.039 *$ & .018 & $.033^{* * * *}$ & .007 \\
\hline Education level of non-LFs & .075 & .157 & -.028 & .057 \\
\hline Income level of non- LFs & .000009 & .000008 & 4.67 & 0.00005 \\
\hline Land Holding (Acres) under LFs & $.818^{*}$ & .320 & .041 & .114 \\
\hline
\end{tabular}




\section{Policy recommendations}

Education regarding livestock insurance is much needed at this stage among livestock farmers because now they are matured in age and they are ready to take this to increase their productivity. Awareness among livestock farmers who are not insured should bring towards livestock insurance through insurance agents, electronic media and print media etc. Role of private institutions and public institutions is much needed to involve livestock farmers in to livestock insurance. Livestock farmers had enough land to under their ownership, so government and private sectors can give them animals/birds to increase their productivity. Veterinary hospitals should be opened in both rural and urban areas to protect the livestock farmers to decrease their losses in the shape of death, diseases and other environmental issues of animals. Livestock farmers were WTP for livestock insurance, so public and private sectors should approach them to give them easy loans and to educate them for livestock insurance.

\section{Conclusion}

Insured and non-insured famers had enough experience in livestock farming and they get loans through banks and insurance agents to increase their productivity and to purchase different animals to get more benefits through loans. Age, land holding area and education level were the significant determinants' of the WTP in both models.

\section{Conflict of interest}

The authors have no conflicts of interest.

\section{References}

1) Banbury, A. 2008. Half of the Pakistan population is food insecure. The news. April 23.

2) Cady, R.A., Shah, S.K., Schermerhorn, E.C., \& McDowell, R.E. 1983. Factors affecting performance of Nili-Ravi buffaloes in Pakistan. Journal of Dairy Science, 66(3), 578-586.

3) Dayanandan, R. 2011. Production and marketing efficiency of dairy farms in highland of Ethiopia: An economic analysis. International journal of enterprise computing and business system. ISSN (online): 2230-8849. $1(5)$.

4) Dua, K., 2001. Incidence, etilogy and estimated economic losses due to mastitis in Punjab and in India an update. Indian Dairyman. 53:41-52

5) Khan, M.Z., \& Khan, A. 2006. Basic facts of mastitis in dairy animals: A review. Pakistan Veterinary Journal, 26(4), 204.

6) Nelson, G.C., Rosegrant, M.W., Koo, J., Robertson, R., Sulser, T., Zhu, T. \& Magalhaes, M. 2009. Climate change: Impact on agriculture and costs of adaptation (Vol. 21). International Food Policy Research Institute.

7) Shabbir R, 2011. Sustainable growth in livestock sector: A case study of Pakistan. Master Thesis, Lund University, Sweden.

8) Thornton, P.K., Kruska, R.L., Henninger, N., Kristjanson, P.M., Reid, R.S., Atieno, F., \& Ndegwa, T. 2002. Poverty and livestock mapping. Final Report to the UK Department for International Development. ILRI, Nairobi, Kenya.

9) Xing, L., Dawei, C., Liping, X., \& Rongqing, Z. 2003. Oral colon-specific drug delivery for bee venom peptide: development of a coated calcium alginate gel beads-entrapped liposome. Journal of Controlled Release, 93(3), 293-300. 